\title{
The Impact Of Audit Committee Multiple-Directorships On Earnings Management: Evidence From France
}

Samir Baccouche, Tunis University, Tunisia

Manel Hadriche, Tunis University, Tunisia

Abdelwehed Omri, Tunis University, Tunisia

\begin{abstract}
The aim of this paper is to examine the relationship between Audit Committee MultipleDirectorships and earnings management. Precisely, we empirically investigate the effect of the multiple directorships held by audit committee directors on the level of earnings management of listed French companies. Our investigation has been achieved on a sample of 88 non financial French listed firms that belong to the SBF 120 index, for the financial year 2008. The results suggest that the accumulation of several outside directorships by audit committee members may lead to a higher degree of earnings management, as measured by the magnitude of discretionary accruals. Therefore, our findings show that audit committee can't provide effective monitoring of earnings management when its members held many additional outside directorships.
\end{abstract}

Keywords: Multiple Directorships; Audit Committee; Earnings Management; Discretionary Accruals

\section{INTRODUCTION}

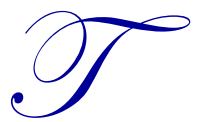

he role of audit committee in ensuring the quality of corporate financial reporting has received great attention in the recent years by accounting and finance researchers. So, several studies has been focused on the relationship between audit committee characteristics and the earnings management (Chang and Sun, 2009; Krishnan et al., 2011; Habbash et al., 2013). In these studies, emphasis was placed mainly on two characteristics of audit committee such as the independence and the financial expertise of its members. These studies showed that the financial expertise of audit committee members and their independence are crucial in constraining earnings management. To this line of research, we propose to study the effect on earnings management of another characteristic of the audit committee, namely multiple directorships of its members.

Recently, the issue of the multiple directorships attracted the attention of researchers and practitioners. A large literature focused on the concept of multiple directorship by directors and its relationships with internal and external characteristics of the firm (Jackling and Johl, 2009; Sarkar and Sarkar, 2009; Jiraporn, et al. 2009; Ahn et al. 2010). In this framework, some studies (Sarkar and Sarkar, 2009; Frye and Wang, 2010) highlighted the benefits of increasing the number of directorships held by directors (e.g., additional experience; firm legitimacy). While others researchers investigated some disadvantages of multiple directorships (e.g., lack of time and efforts) and asked legislators to impose restrictions on the number of directorships held by a director to make it more effective (Devos et al., 2009; Jiraporn et al., 2009b; Sharma and Iselin, 2012). These studies about the consequences of multiple directorships are thus inconclusive so far, and they do not focus on the effect of multiple directorships on financial information quality. Also, most of these studies examined multiple directorships at the board level. All this motivated us to study multiple directorships held by directors at the audit committee level with special emphasis on the impact of multiple directorships of audit committee members on earnings management. In fact, in order to improve their reputation and to be more valued in the market (Fama and Jensen, 1983), the audit committee directors may accumulate outside directorships (Jiraporn et al., 2009 a). However, the problem that emerges is to know if this committee can be effective in reducing earnings management in the case where their members accumulate many directorships. 
In this paper, we try to extend the literature on earnings management to the French context by studying the relationship between audit committee multiple-directorships and earnings management of listed French companies. To our knowledge, although there is a special attention paid to the issue of the multiple directorships in this French setting, there are few studies in this context that examine multiple directorships at audit committee level. Moreover, in France, the New Economic Regulations Law (2001) limited the number of directorships that a director can hold at the same time, so that he can be more effective by spending more time to his monitoring duties. Likewise, the section (L225-21) of the French Commercial Code (2008) required that "No natural person shall concurrently hold more than five directorships of limited companies having their registered office on French soil ..." (Commercial code, 2008; pp.60). This law gives thus possibility to the individual to hold additional board seats in non limited companies or in those having their headquarters outside the French territory. So, directors of French companies can hold too many directorships at the same time (more than five outside directorships). Thereby, for the French context, it seems interesting to understand if the accumulation of outside board seats by audit committee directors affects the level of earnings management in a firm.

Using a sample of 88 non financial firms belonging to the SBF 120 index during the financial year 2008, we examine if the level of discretionary accruals is related to the multiple directorships of audit committee directors. Discretionary accruals estimated by the Kothari et al. (2005) model are used as a proxy for earnings management on the firm. The results of our estimation confirm the existence of a positive link between the multiple directorships of audit committee directors and the magnitude of discretionary accruals in the firm. Otherwise, we find that the accumulation of outside directorships by audit committee directors can raise the busyness of this committee. So, it will have less available time and will become unable to monitor managers' discretionary behavior effectively; which may increase the intensity of earnings management in the company.

This research contributes to the literature in different ways. Firstly, this paper contributes to the existing literature on multiple directorships into the area of audit committee. It contributes also to the existing literature on earnings management by investigating audit committee's role in reducing earnings management from a new perspective: audit committee multiple-directorships. Secondly, our results may give some guidance to French companies that are seeking to reinforce the effectiveness of their audit committees. Thirdly, our research provides policy advice for other francophone contexts by documenting that the restriction of the number of directorships held by audit committee directors is an important factor in reducing the earnings management.

The remainder of this paper is organized as follows. In the next section, we present the literature review on relationship between earnings management and the accumulation of directorships by audit committee directors, and we develop the hypotheses to be tested. In the third section, we describe empirical methodologies. In the last section, we discuss the results of our empirical study and we draw the conclusions.

\section{AUDIT COMMITTEE MULTIPLE DIRECTORSHIPS AND EARNINGS MANAGEMENT: LITERATURE REVIEW}

The literature on earnings management turns principally around the agency theory which suggests that the interests of managers do not align all the time with those of shareholders. Managers can use earnings management which is defined as an intervention in the financial reporting process to extract rents from shareholders and improve their private profits (Healy and Wahlen, 1999). In fact, managers can undertake earnings management to lower the likelihood of dismissal when performance is very low. Also, they can use it to increase their compensation and to reassure investors on non-violation of their contracts (Dechow et al., 2010).

The principal body responsible for the monitoring of management is the board of directors with the assistance of its created committees (Vienot, 1995). In fact, in order to facilitate their activities, boards of directors might delegate responsibilities and important tasks to their monitoring committees. The committee responsible for financial reporting oversight is the audit committee, which is consisting of the members of the board. The audit committee can help in protecting the interests of shareholders by maintaining the credibility of firm's financial reports. Laux and Laux (2009) have shown that one of the most important role of audit committee is to prevent and detect any earnings management practices in order to have reliable financial statements and accurate information about the firm. The creation of the audit committee is among the trend on corporate governance. 
Prior research does not lead to clear conclusions about audit committee effectiveness in reducing earnings management. For example, Beasley (1996) showed that an audit committee does not reduce greatly the fraud and earnings management practices. Nevertheless, other authors such as Piot and Janin (2007) reported that the creation of an audit committee reduces the earnings management in the French firms. Moreover, there is an emergent empirical literature that focuses on the relationship between audit committee characteristics and earnings management. In this respect, some authors found that audit committee independence can mitigate earnings management (Klein, 2002; Chang and Sun, 2009; Kang et al., 2011; Alkdai and Hanefah, 2012). In this paper, we are interested in another audit committee characteristic that can have influence on the earnings management. Particularly, we focus on audit committee multiple-directorships. In their research, DeZoort and Salterio (2001) detected a positive association between the number of directorships simultaneously occupied by audit committee directors and the financial information quality. Also, Vafeas (2005) proved that the number of external board seats held by audit committee members improves the financial reporting quality because these directors have an incentive to protect their reputation (Fama and Jensen, 1983). Some researchers affirmed that the members who serve many outside directorships are more active and motivate to attend board and internal committees meetings (Sarkar and Sarkar, 2009). The participation in frequent meetings can help these busy audit committee directors to interact and to coordinate with others audit committee members which improves their effectiveness in constraining earnings management. In this respect, Xie et al. (2003) argued that members who meet frequently can enhance their monitoring capacities which reduce the earnings management behavior of managers. Furthermore, using a sample of 250 US firms, Yang and Krishnan (2005) investigated the relationship between audit committee characteristics and quarterly earnings management. Using discretionary accruals as a measure of quarterly earnings management, they found that the average number of outside directorships held by audit committee directors is significantly associated with lower discretionary accruals. So, Yang and Krishnan (2005) confirmed that the exercise of many outside directorships by audit committee members can reduce earnings management behavior. The results of their study showed that audit committee directors with multiple directorships are motivated to engage in greater monitoring in order to maintain their expertise and reputation as good monitors (Fama and Jensen, 1983). Accordingly, we suppose that the multiple directorships held by audit committee members may provide a committee with added capacities, which can reduce the level of earnings management. This leads to pose the following hypothesis:

H1: There is a negative relation between multiple directorships of audit committee members and the magnitude of earnings management.

On the other hand, several studies failed to support the negative association between the accumulation of outside directorships by audit committee members and the extent of earnings management. These researches advanced that monitoring of top management's behavior need more effort and available time, and demand directors with less number of directorships served (Booth and Deli, 1996). In fact, Beasley (1996) proved that the likelihood of fraud rises when outside directors serve simultaneously more than two seats in other boards. In that sense, the accumulation of directorships isn't beneficial for audit committee when its members hold multiple outside board seats at the same time. The major problem that can be faced by audit committee directors is the lack of time needed to perform their monitoring tasks (Morck et al., 1988). However, the holding of multiple directorships by an audit committee director can reduce the time that he must devote to its various directorships served (Jiraporn et al., 2009 b). So, the accumulation of directorships may make the audit committee directors busier. Thus, they will be less attentive and unable to monitor the discretionary behavior of managers effectively (Jiraporn et al., $2009 \mathrm{~b}$; Sharma and Iselin, 2012; Pathak and Sun, 2012). In their research, Jiraporn et al. (2009 a) advanced that directors who hold multiple directorships at the same time are unable to attend all committees meetings which reduce their ability to monitor the opportunistic behavior of managers. Consequently, managers will be less controlled and may have more freedom, which motivates them to increase their earnings management practices. Accordingly, this leads us to test the following hypothesis:

H2: There is a positive relation between multiple directorships of audit committee members and the magnitude of earnings management. 


\section{EMPIRICAL METHODOLOGIES}

The purpose of this research is to investigate the effect of multiple directorships held by audit committee members on earnings management. To test our hypotheses, we use a multiple linear regression model which regress the measure of earnings management on the independent variable and on a set of control variables. In what follows, we discuss data and sample, variables measurement, and model specification.

\subsection{Data and Sample}

This research involves a cross-sectional investigation of 88 non financial French listed companies that belong to the SBF 120 index, for the financial year 2008. From 120 listed companies of the SBF 120 index, 21 financial and foreign companies are dropped because they have distinctive features and they are subject to specific regulations; 11 other companies are dropped due to the lack of some specific information about their audit committee. Information pertaining to audit committee characteristics and financial information were obtained from annual reports published by these studied firms. All data are hand-collected from these reports and website of companies. We study the financial year 2008 because the French commercial code that has limited the number of directorships that a director can hold to five is brought into force in 2008.

\subsection{Variables Measurement}

\subsubsection{Measurement of Earnings Management}

According to earlier researches, the magnitude of discretionary accruals can be used as a proxy for the extent of earnings management (Klein, 2002; Davidson et al., 2005; Alves, 2012). To better estimate the magnitude of discretionary accruals, we evaluate the discretionary accruals using the Kothari et al. (2005) model. We use this model, because Kothari et al. (2005) proved by a set of statistical tests that the performance-matched discretionary accruals model is most robust to detect earnings management particularly in profitable firms; and we found that on average French firms are profitable. Thus, this Kothari et al. (2005) model seems be more adaptable to the French context. This model is as follows:

$$
(\text { TAcci,t/ATi,t-1) }=\alpha 0+\alpha 1(1 / \text { ATi,t-1) }+\alpha 2(\Delta \text { REVi,t } / \text { ATi,t-1 })+\alpha 3(\text { PPEi,t } / \text { AT i,t-1 })+\alpha 4 \text { ROAi,t-1 }+\varepsilon i, t
$$

TAcci, $\mathrm{t}=$ Total Accruals of the company; PPEit = Property, plant and equipments of the company; $\Delta \mathrm{REVi}, \mathrm{t}=$ Change in Revenue of the company; ATi, $t-t=$ Assets total of the company in year t-1; ROA i,t-1= Return On Assets of the company in year $\mathrm{t}-1 ; \varepsilon=$ random error term

The coefficients $(\tilde{\alpha} 0 ; \tilde{\alpha} 1 ; \tilde{\alpha} 2 ; \tilde{\alpha} 3 ; \tilde{\alpha} 4)$ obtained from the estimation of regression above are used to defining the value of non discretionary accruals scaled by the lagged total assets of the firm (NDA). Thus, the non discretionary accruals deflated by lagged total assets are calculated as follows:

$$
\begin{aligned}
& \mathrm{NDA}_{\mathrm{it}}=\tilde{\alpha}_{0}+\tilde{\alpha}_{1}\left(1 / \mathrm{AT}_{\mathrm{i}, \mathrm{t}-1}\right)+\tilde{\alpha}_{2}\left(\Delta \mathrm{REV}_{\mathrm{i}, \mathrm{t}} / \mathrm{AT}_{\mathrm{i}, \mathrm{t}-1}\right)+\tilde{\alpha}_{3}\left(\mathrm{PPE}_{\mathrm{i}, \mathrm{t}} / \mathrm{AT}_{\mathrm{i}, \mathrm{t}-1}\right)+\hat{\mathrm{w}}_{4} \mathrm{ROA}_{\mathrm{i}, \mathrm{t}-1} \\
& \mathrm{DA}_{\mathrm{it}}=\left(\mathrm{TAcc}_{\mathrm{i}, \mathrm{t}} / \mathrm{AT}_{\mathrm{i}, \mathrm{t}-\mathrm{l}}\right)-\mathrm{NDA}_{\mathrm{i}, \mathrm{t}}
\end{aligned}
$$

These discretionary accruals will be used as a proxy for earnings management in French firms. Thus, we use the absolute value of discretionary accruals (DA) as a proxy of the magnitude of earnings management (Piot and Janin, 2007; Qi and Tian, 2012; Al-Zyoud, 2012).

\subsubsection{Measurement of Audit Committee Multiple-Directorships}

Majority of the researchers have used the average number of outside directorships held by audit committee members to evaluate the audit committee multiple-directorships (Yang and Krishnan, 2005; Kang et al., 2011). However, in their study of the level of outside directorships held by board members, Sarkar and Sarkar (2009) showed that is more accurate to use the median than the average number of outside directorships. The median has 
the advantage of eliminating the extreme observations and reflecting the multiple directorships of the majority of directors (Sarkar and Sarkar, 2009). Therefore, our independent variable (OUTDIR) is measured as the median of the number of outside directorships held by audit committee directors.

\subsection{Model Specification}

The model used to examine the impact of audit committee multiple directorships on the magnitude of earnings management was inspired by the survey of Yang and Krishnan (2005) on which we make some change in the French context. Thus, to test our hypotheses, we use the following model:

DA $=\beta_{0}+\beta_{1}$ OUTDIR $+\beta_{2}$ ACSIZE $+\beta_{3}$ INDAC $+\beta_{4}$ NREUAUD $+\beta_{5}$ TENURE $+\beta_{6}$ AUDOWN $+\beta_{7}$ NDEAR + $\beta_{8} \mathrm{LEV}+\beta_{9} \mathrm{ROA}+\beta_{10} \mathrm{SIZE}+\xi$

DA: absolute Discretionary Accruals as calculated by using the Kothari et al. (2005) model; OUTDIR: Outside directorships held by audit committee directors; ACSIZE: Audit committee size; INDAC: percentage of independent members on the audit committee; TENURE: the average tenure of audit committee directors on the board; AUDOWN: percentage of company's stock owned by audit committee members; ACMEET: Audit committee meetings; NDEAR: Nondiscretionary earnings; SIZE: Firm size; LEV: Leverage; ROA: Return on asset ratio.

Table 1: Variables Measurement

\begin{tabular}{l|ll}
\hline \multicolumn{1}{l}{ Variables Measurement } \\
\hline OUTDIR & The Absolute discretionary accruals calculated using Kothari model \\
TCSIZE & The number of audit committee members \\
INDAC & The percentage of independent directors on audit committee \\
ACMEET & The number of meetings of the audit committee \\
TENURE & The average numbers of years the audit committee members have served in the board of directors. \\
AUDOWN & The percentage of the firm shares detained by audit committee directors in the firm \\
NDEAR & The nondiscretionary earnings variable \\
LEV & The debt-to-total assets ratio \\
ROA & The net income-to-total assets \\
SIZE & The logarithm of total assets \\
\hline
\end{tabular}

\section{RESULTS AND DISCUSSION}

\subsection{Descriptive Statistics and Tests}

Table 2 provides descriptive statistics of different variables used in our analysis. According to this table, the average absolute value of discretionary accruals, for the French firms that constitute our sample, is 5.3\% of assets. Thereby, we can say that managers of French companies tend to manage firm's earnings. Furthermore, the table 2 shows that the average level of multiple directorships by audit committee members is between four and five outside directorships by director. Thereby, we can say that on average French firms that constitute our sample have busy audit committees. The busyness of these audit committees can reduce their ability to monitor the process of preparation of financial statements effectively and to limit the opportunistic behavior of managers, which might increase earnings management in firms.

The descriptive statistics reported in table 2 also indicate that the average size of the audit committee in French firms is between three and four members. In addition, the proportion of independent members on this committee is, on average, high with a percentage of about $67 \%$. So, French firms tend to include more independent directors in their audit committees. These results seem to meet the recommendations of French reports, especially Vienot $(1995,1999)$ and Bouton (2002). The results show also that the average number of audit committee meetings is equal to five meetings per year (4.76) and that their members spend, on average, between five and six years on the board of their companies. Furthermore, we perceive that audit committee members own, on average, about $0.06 \%$ of 
the shares of their firms. This level of stock ownership seems to be low to motivate audit committee members to provide more effort in monitoring earnings management. From the table above, we notice also that the nondiscretionary earnings of French firms represent, on average, (-0.015) of their total assets. This may explain the incentive of managers to manage firm's earnings. The statistics reported in table 2 indicate also that French companies had an average size of 4009.6 million of euro $\left(\mathrm{e}^{8.296}\right)$, and had an average debt to total assets ratio of around $27 \%$. In addition, the return on assets ratio of these firms is on average about $6 \%$. Therefore, we can say that the firms included in our sample are on average profitable.

Table 2: Descriptive Statistics

\begin{tabular}{|c|c|c|c|c|c|}
\hline & & Mean & Std dev & Min & Max \\
\hline \multirow{11}{*}{ 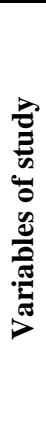 } & $\overline{\mathrm{DA}}$ & 0.053 & 0.083 & 0.00003 & 0.395 \\
\hline & OUTDIR & 4.619 & 2.954 & 0 & 12 \\
\hline & ACSIZE & 3.53 & 1.124 & 2 & 7 \\
\hline & INDAC & 0.669 & 0.286 & 0 & 1 \\
\hline & ACMEET & 4.761 & 2.160 & 0 & 12 \\
\hline & TENURE & 5.53 & 3.731 & 2 & 19 \\
\hline & AUDOWN & 0.0006 & 0.002 & 0.000 & 0.017 \\
\hline & NDEAR & -0.015 & 0.036 & -0.141 & 0.167 \\
\hline & LEV & 0.271 & 0.154 & 0.004 & 0.714 \\
\hline & ROA & 0.061 & 0.067 & -0.346 & 0.205 \\
\hline & SIZE & 8.296 & 5.831 & 3.107 & 10.215 \\
\hline
\end{tabular}

Before proceeding to the regression analysis, it was necessary to run several statistics tests to make sure that there was no violation of the OLS assumptions of multicollinearity between explanatory variables, homoscedasticity and normality of the error terms. It is essential to pay a special attention to the correlation among explanatory variables in order to avoid multicollinearity problem. In fact, the linear regression requires the absence of multi-collinearity among these variables. To verify this condition, we use the correlation matrix and the variance inflation factors (VIFs) for explanatory variables, as presented in the table 3 below. According to this table, we notice that the correlation coefficients among explanatory variables are very small; all coefficients are less than 0.5 . Therefore, correlation coefficients among explanatory variables indicate that the regression analysis is free from multicollineartity problem. This conclusion is also justified by the VIFs test. In fact, all variance inflation factor values are fairly small than 5 (all VIF values are between 1 and 1.3), confirming that multicollinearity is not a problem in our model.

Table 3: Correlation Matrix and VIFs

\begin{tabular}{|c|c|c|c|c|c|c|c|c|c|c|c|}
\hline & \multicolumn{10}{|c|}{ Correlation Matrix for Explanatory Variables } & \multirow{2}{*}{ VIF } \\
\hline & ACSIZE & INDAC & SIZE & LEV & ROA & TENURE & AUDOWN & NDEAR & ACMEET & OUTDIR & \\
\hline ACSIZE & & & & & & 1 & & & & & 1.133 \\
\hline INDAC & -0.071 & 1 & & & & & & & & & 1.110 \\
\hline SIZE & -0.115 & -0.048 & 1 & & & & & & & & 1.084 \\
\hline LEV & -0.132 & -0.003 & 0.040 & 1 & & & & & & & 1.087 \\
\hline ROA & 0.003 & -0.110 & 0.139 & -0.128 & 1 & & & & & & 1.244 \\
\hline TENURE & 0.035 & 0.081 & 0.057 & -0.025 & 0.083 & 1 & & & & & 1.055 \\
\hline AUDOWN & -0.170 & -0.209 & 0.113 & -0.094 & 0.179 & -0.132 & 1 & & & & 1.222 \\
\hline NDEAR & 0.029 & 0.027 & -0.014 & -0.173 & 0.163 & 0.002 & -0.137 & 1 & & & 1.131 \\
\hline ACMEET & 0.219 & -0.039 & -0.116 & 0.019 & -0.307 & -0.067 & -0.125 & 0.105 & 1 & & 1.215 \\
\hline OUTDIR & 0.033 & -0.137 & -0.193 & -0.047 & -0.022 & -0.105 & -0.130 & 0.122 & 0.107 & 1 & 1.118 \\
\hline
\end{tabular}

The Skewness and kurtosis test results, as presented in the table 4 below, indicate that the null hypothesis of residuals normality can be accepted at $5 \%$ significance level $((\mathrm{P}>\mathrm{Chi} 2)=0.91>0.05)$. Thus, the test confirms that the residuals of our model are normally distributed. The Breusch-Pagan test is used to detect the heteroscedasticity problem by testing the null hypothesis of homoscedasticity of residuals (H0: the residuals' variance is constant). In this case, the results indicate that the residuals are homoscedastic. Therefore, no heteroscedasticity problem is found in the regression model. The Ramsey RESET test is used to test for omitted variable bias. The results of the Ramsey RESET test show a p-value higher than the threshold of $5 \%((\mathrm{P}>\mathrm{F})=0.48>0.05)$. So, we fail to reject the null 
hypothesis and we can conclude that there is no omitted variables bias in our results. Since the regression model satisfies the assumptions of OLS (Ordinary least-squares) regression, we can therefore estimate our model using the OLS method.

Table 4: Statistical Tests

\begin{tabular}{|l|c|}
\hline Skewness and Kurtosis Test for Normality & Chi2 $(2)=0.18 ;(\mathrm{P}>$ Chi2 $)=0.913$ \\
\hline Ramsey's RESET Test & $\mathrm{F}(3,74)=0.83 ;(\mathrm{P}>\mathrm{F})=0.481$ \\
\hline Breusch-Pagan Test & $\mathrm{Chi} 2(1)=0.31 ;(\mathrm{P}>\mathrm{Chi} 2)=0.577$ \\
\hline
\end{tabular}

\subsection{Regression Analysis}

Table 5 reports the results of the regression model. Based on this table, we notice that the adjusted- $\mathrm{R}^{2}$ value is 0.211 , which implies that $21.1 \%$ of the variation in the dependant variable (DA) is explained by the variation in the explanatory variables of the model. Thereby, we can affirm that the goodness of fit of our model is relatively good. Based on the F-test, we can also see that our model is globally significant at $1 \%$ level (p-value $<0.01$ ). So, we can conclude that all explanatory variables included in our model explain the dependant variable well.

The results of the estimation of our regression model are represented in table 5. From this table, we notice that the average level of multiple directorships held by audit committee members affects positively and significantly the magnitude of discretionary accruals in French firms. In that sense, the accumulation of several outside directorships by audit committee members may lead to a higher degree of earnings management in French companies as measured by the magnitude of discretionary accruals. This positive relationship can be explained by the unavailability and the busyness of the audit committee members. Indeed, the accumulation of several outside directorships can reduce the concentration and the time devoted by the audit committee members to their task of monitoring the process of preparation of financial statements and the quality of information to disclose. In addition, busy members are often less able to attend audit committee meetings (Jiraporn et al., 2009a), which weakens their coordination ability and therefore reduce their capacity to control the managers and to detect earnings management practices. So, being less supervised, managers will then have more chance to manage earnings in order to generate private advantages. The magnitude of discretionary accruals in French firms is, therefore, more influenced by the lack of time devoted by busy audit committee members to their monitoring tasks, than by the expertise gathered from the accumulation of several outside directorships. This can be explained by the fact that the tasks performed by the audit committee require expertise and mainly high availability of its members to be executed effectively (Jiraporn et al., 2009b). So, our result confirms those of Morck et al. (1988), Booth and Deli (1996), Jiraporn et al. (2009b) and Pathak and Sun (2012). These researchers have shown that the accumulation of outside directorships by directors may reduce their ability and their time devoted to the audit committee's monitoring tasks. Thereby, managers can easily manage the earnings of the firm by increasing the discretionary accruals.

Table 5: Effect of Multiple Directorships Held by Audit Committee Directors on the Magnitude of Discretionary Accruals

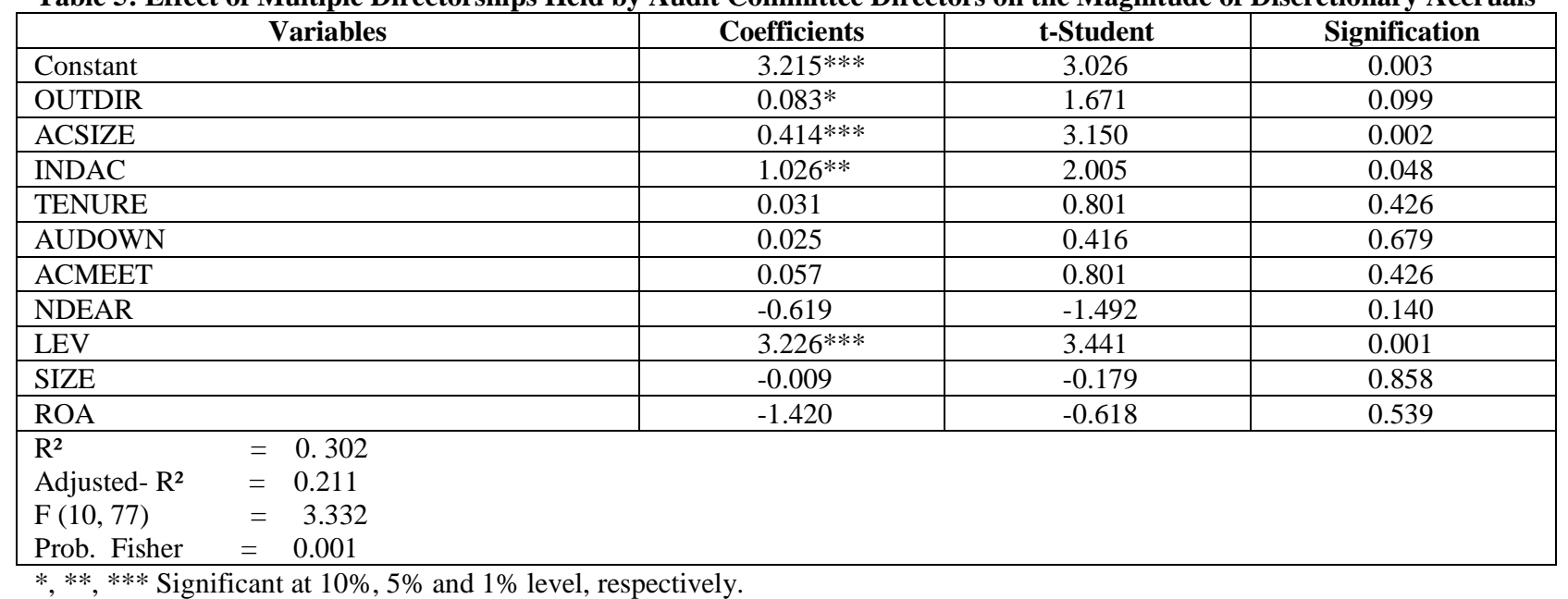


Table 5 also shows that the size of the audit committee affects the magnitude of discretionary accruals positively and significantly at the $1 \%$ level. This positive effect can be explained by the problems of communication and the difficulties of sharing responsibility suffered by the large audit committees (Karamanou and Vafeas, 2005). These difficulties may restrict the ability of the committee to control earnings management practices and the process of preparation of financial statements, which can give more freedom for managers to manage earnings of the firm easily.

We find also that the independence of the audit committee affects the level of discretionary accruals positively and significantly at the 5\% level. This result can be explained by the principle of collegiality in controlling the quality of financial information (Bouton, 2002). In fact, the Bouton report specifies that: "The audit committee should not indeed substitute for the board of directors, but be an emanation which facilitates the work of the board" (Bouton, 2002; pp. 11). In that sense, although it plays an important role in monitoring the quality of financial statements, the audit committee seems to have a consultative role to the board of directors. This consultative role can demotivate independent members to monitor the process of preparation of financial statements effectively, which may give more opportunities for managers in French firms to increase their opportunistic earnings management (Piot and Janin, 2007). The highly participation of independent members on the audit committee may also lead to less communication and share of information between them, especially, since they can be absent from some committee meetings. These members will be therefore more dependent on the manager in order to gather internal information (Harris and Raviv, 2008). Thereby, the manager will have more influence on the audit committee directors and he will have more liberty and opportunities to manage the earnings of the firm. At this level, we notice that this positive relationship corroborates the findings of Piot and Janin (2007) in the French context. We find moreover that the level of leverage affects the magnitude of discretionary accruals positively and significantly at the $1 \%$ level. This positive relationship may be explained by the fact that highly leveraged firms are motivated to manage their earnings by increasing discretionary accruals, in order to convince borrowers and to prove their solvency. This might help them to negotiate the terms of their loans and to respond easily to their financing needs with lower costs. However, the results show also that no other variables in the regression model have any impact on earnings management.

\section{CONCLUSION}

Using a sample of 88 non financial French listed companies belonging to the SBF 120 index, during the financial year 2008, we find that the magnitude of earnings management in French firms is an increasing function of the mean (median) level of multiple directorships held by audit committee members. In other words, if the audit committee members undertake on average an additional number of outside directorships, the level of earnings management increase. Our findings thus show that audit committee can't provide effective monitoring of earnings management when its members hold too many outside directorships. The accumulation of many directorships can reduce the available time of the audit committee members and make them busier, so they become unable to control the discretionary behavior of managers effectively and to constrain the earnings management practices. These results suggest, therefore, that the earnings management in French firms is more influenced by the lack of time devoted by busy audit committee members to their monitoring tasks, than by the reputation and the expertise gathered from the accumulation of outside directorships. Thus, our study recommends that audit committee members shouldn't hold many outside directorships. Furthermore, our results show that the size of the audit committee and the independence of its members are significantly associated with higher level of earnings management. Our findings also prove that there is a positive relation between the magnitude of earnings management and the level of leverage in the firm.

This paper contributes to the existing literature by studying the effect of audit committee on earnings management from a new perspective: audit committees multiple-directorships. We provide considerable evidence on the link between audit committee multiple-directorships and corporate earnings.

The results of this paper have implications for firms seeking to improve their audit committee effectiveness. Thereby, the results must encourage companies to avoid the appointment of directors holding multiple directorships or to reduce the number of outside directorships held by members of its audit committee, this if they want to improve the quality of financial information disclosed. Moreover, the findings of this paper have implications for investors in understanding the effect of audit committee multiple-directorships on corporate 
earnings. According to our results, investors should see multiple directorships of audit committee members as a threat. Furthermore, the results of this study may have implications for regulators who are concerned to reduce opportunities for earnings management and to improve financial reporting quality. Practically, the findings of this study provide some meaningful insights for the decision makers and policy makers in terms of the role of audit committee in enhancing the reliability of the financial reporting process and the information content of accounting earnings. Investors and shareholders too should be aware of management's capacity to alter accounting earnings for opportunistic purposes. Our findings in general support the French regulatory authority laws that require firms to limit the number of outside directorships that a director can hold simultaneously. So, our study recommends, for other francophone contexts, the imposition of limits on the number of directorships held by audit committee members if they seek to improve financial reporting quality.

The results and implications of our research are subject to several limitations that suggest future research. Firstly, due to difficulties in collecting data, the sample size of our research is relatively small and the period of the study is short compared to some studies examining earnings management. Future research could use larger sample and longer period when data becomes more available. Secondly, our model did not include all new governance variables that may affect the extent of earnings management. Thus, future research on earnings management may include and analyze the impact of others new governance variables related to the ownership structure or the compensation of CEO on the magnitude of earnings management.

\section{AUTHOR INFORMATION}

Samir Baccouche is a PhD in Management at the Higher Institute of Management of Tunis and member of GEF2A laboratory. He received his PhD from Tunis University, Higher Institute of Management, 2012. E-mail: samir27d@ hotmail.com

Manel Hadriche is an Assistant Professor in Accounting at the Faculty of Economic Sciences and Management of Nabeul Tunisia and member of GEF2A laboratory. Dr Hadriche has published several research papers in various academic journals. E-mail: manel.hadriche@yahoo.fr (Corresponding author)

Abdelwehed Omri is a Professor of Accounting and finance at Tunis University and director of GEF2A laboratory. E-mail: abdelomri@gmail.com

\section{REFERENCES}

1. Ahn, S., Jiraporn, P. and Kim, Y. (2010). Multiple directorships and acquirer returns. Journal of Banking and Finance, 34 (9) 2011-2026.

2. Al-Zyoud, A. (2012). The Effects of Chairman Independence and Ownership Structure on Earnings Management. World Applied Sciences Journal, 17 (18) 934-940.

3. Alkdai, H. K. H. \& Hanefah, M.M. (2012). Audit committee characteristics and earnings management in Malaysian Shariah-compliant companies. Business and Management Review, 2(2) 52 - 61.

4. Alves, S. (2012). Ownership Structure and Earnings Management: Evidence from Portugal. Australasian Accounting Business and Finance Journal, 6 (1) 57-74.

5. Beasley, M. (1996). An empirical analysis of the relation between the board of director composition and financial statement fraud. The Accounting Review, 71 (4) 443-465.

6. Booth, J. \& Deli, D. (1996). Factors affecting the number of outside directorships held by CEOs. Journal of Financial Economics, 40 (1) 81-104.

7. Chang, J. \& Sun, H. (2009). Crossed-listed foreign firms' earnings informativeness, earnings management and disclosures of corporate governance information under SOX. The International Journal of Accounting, 44 (1) $1-32$.

8. Davidson, R., Goodwin-Stewart, J. and Kent, P. (2005). Internal governance structures and earnings management. Accounting and Finance, 45 (2) 241-267.

9. Dechow, P., Ge, W. and Schrand, C. (2010). Understanding earnings quality: A review of the proxies, their determinants and their consequences. Journal of Accounting and Economics, 50(2/3) 344-401. 
10. Devos, E., Prevost, A. and Puthenpurackal, J. (2009). Are interlocked directors effective monitors? Financial Management, 38 (4) 861-887.

11. DeZoort, F. \& Salterio, S. (2001). The effects of corporate governance experience and financial reporting and audit knowledge on audit committee members' judgments. Auditing: A Journal of Practice and Theory, 20 (2) 31-47.

12. Fama, E. \& Jensen, M. (1983). The separation of ownership and control. Journal of Law and Economics, 26 (2) $301-325$.

13. Frye, M. \& Wang, W. (2010). Boards, uncertainty and the use of fairness opinions. Corporate Governance: An International Review 18 (1) 48-63.

14. Habbash, M, Sindezingue, C. and Salama, A. (2013).The effect of audit committee characteristics on earnings management: Evidence from the United Kingdom. International Journal of Disclosure and Governance, 10 (1)13-38.

15. Harris, M. \& Raviv, A. (2008). A theory of board control and size. Review of Financial Studies, 21(4) 17971832.

16. Healy, P. \& Wahlen, J. (1999). A review of the earnings management literature and its implications for standard setting. Accounting Horizons, 13 (4) 365-403.

17. Jensen, M. (1993). The modern industrial revolution, exit, and the failure of internal control systems. Journal of Finance, 48 (3) 831-880.

18. Jiang, W., Lee, P. and Anandarajan, A. (2008). The association between corporate governance and earnings quality: Further evidence using the GOV-Score. Advances in Accounting, Incorporating Advances in International Accounting, 24 (2) 191-201.

19. Jiraporn, P., Davidson, W., DaDaltc, P. and Ning, Y. (2009 a). Too busy to show up? An analysis of directors' absences. The Quarterly Review of Economics and Finance, 49 (3) 1159-1171.

20. Jiraporn, P., Singh, M. and Lee, C. (2009 b). Ineffective corporate governance: Director Busyness and board committee memberships. Journal of Banking and Finance, 33 (5) 819-828.

21. Kang, W., Kilgore, A. and Wright, S. (2011). The effectiveness of audit committees for low- and mid-cap firms. Managerial Auditing Journal, 26 (7) 623-650.

22. Klein, A. (2002). Audit committee, board of director characteristics, and earnings management. Journal of Accounting and Economics, 33 (3) 375-400.

23. Kothari, S., Leone, A. and Wasley, C. (2005). Performance matched discretionary accrual measures. Journal of Accounting and Economics, 39 (1) 163-197.

24. Krishnan, J., Wen, Y. and Zhao, W. (2011). Legal Expertise on Corporate Audit Committees and Financial Reporting Quality. The Accounting Review, 86 (6) 2099-2130.

25. Laux, C. \& Laux, V. (2009). Board committees, CEO compensation and earnings management. The Accounting Review American, 84 (3) 869-891.

26. Morck, R., Shleifer, A. and Vishny, R. (1988). Management ownership and market valuation. Journal of Financial Economics, 20 (1/2) 293-315.

27. Pathak, J. \& Sun, J. (2012). Does investor protection regime affect the effectiveness of outside directorship on the board? Journal of Multinational Financial Management, In Press.

28. Piot, C. \& Janin, R. (2007). External auditors, audit committees and earnings management in France. European Accounting Review, 16 (2) 429-454.

29. Qi, B. \& Tian, G. (2012). The Impact of Audit Committees' Personal Characteristics on Earnings Management: Evidence from China. The Journal of Applied Business Research, 28 (6) 1331-1343.

30. Sarkar, J. \& Sarkar, S. (2009). Multiple board appointments and firm performance in emerging economies: Evidence from India. Pacific-Basin Finance Journal, 17 (2) 271-293.

31. Sharma, D. \& Iselin, R. (2012). The Association between Audit Committee Multiple-Directorships, Tenure, and Financial Misstatements. Auditing: A Journal of Practice \& Theory, 31 (3) 149-175.

32. Vafeas, N. (2005). Audit committees, boards and the quality of reported earnings. Contemporary accounting research, 22 (4) 1093-1122.

33. Xie, B., Davidson, W. and DaDalt, P. (2003). Earnings management and corporate governance: the role of the board and the audit committee. Journal of Corporate Finance, 9 (3) 295-316.

34. Yang, J. \& Krishnan, J. (2005). Audit committees and quarterly earnings management. International Journal of Auditing, 9 (3) 201-219. 